\title{
Building refurbishment to passive house standards of the quarter Brogården in Alingsås, Sweden
}

\author{
Heimo Zinko ${ }^{1 *}$ \\ ${ }^{1}$ Linköping University, Linköping, Sweden \\ * Corresponding author. Tel: +46 155 58344, Fax +46155 282545, e-mail: zinko@algonet.se
}

\begin{abstract}
In Sweden, the transition of the society from agricultural to industrial occupation caused millions of people to move from the country-side into cities and in the 1960-ies and 1970-ies a broad building construction program was performed in order to build 1 million new dwellings in Sweden. However, these buildings are now after 40 years under urgent need of refurbishment and therefore offer a great opportunity for being supplied with modern and efficient construction details and heating systems. An example of such a project is the refurbishment of residential buildings in the quarter Brogården of Alingsås, were 16 buildings with 300 dwellings are to be converted from 1970-standards to modern passive house standards. The housing company Alingsåshem has in partnership with the construction company Skanska and under the consultancy of efem architects and the local Passive House Centrum started a refurbishment project for Brogården. The project involves the extensive renovation of the buildings with passive house techniques, and includes the installation of new façades and roofs, thicker insulation and new ventilation systems. The refurbished buildings do not use conventional heating systems and require very little energy for space heating. Hot water is primarily produced by solar energy, peak load energy is supplied by district heating,
\end{abstract}

Keywords: Building refurbishment, Passive house, Energy efficiency, Urban development

\section{Introduction}

In order to fulfil EU's action Plan for Energy Efficiency from 2006 it is important to apply energy saving measures not only to new buildings but also to existing buildings. In Sweden, like in many other countries, this is a very important issue with a high potential as reduced energy use for heating purposes is concerned. The transition of the society from agricultural to industrial occupation caused millions of people to move from the country-side into cities and in the 1960-ies and 1970-ies a heavy building construction program was therefore performed in order to create 1 million new dwellings in Sweden. However, these buildings are now after 40 years under urgent need of refurbishment and therefore offer a great opportunity for getting renovated and supplied with modern and efficient construction details and heating systems [1]. In Sweden, this could mean that EUs plans for energy efficiency for both 2020 and 2050 could well be met.

\subsection{Objective}

This paper presents the refurbishment project in Alingsås, Sweden, performed by the municipality-owned housing company Alingsåshem, which is in train to renovate 16 buildings with 300 apartments to passive house standard. The project is affecting about 650 people. It started 2008 with the renovation of the first building with 18 apartments indented to serve as a demonstration and for motivating the tenants to undergo the total construction work and to accept all the inconveniencies during the refurbishment. Up to the end of 2010, 4 of the 16 buildings have been renovated and again taken into use.

In this paper, the important features of the refurbishment task and its planning is shortly described as well as first experiences from living in the new apartments. 


\section{General project information}

The housing company Alingsåshem is owned by the municipality Alingsås which applies a policy of "serving the tenants with the different needs which occur in the housing sector and to contribute to a sustainable habitation". The owner has a. o. specified that Alingsåshem should

- offer the inhabitants of the city an attractive and secure residence

- offer a varying and interesting selection of dwellings

- offer good availability and integration for everyone

- be responsible for that planning and construction of dwellings meets the demands.

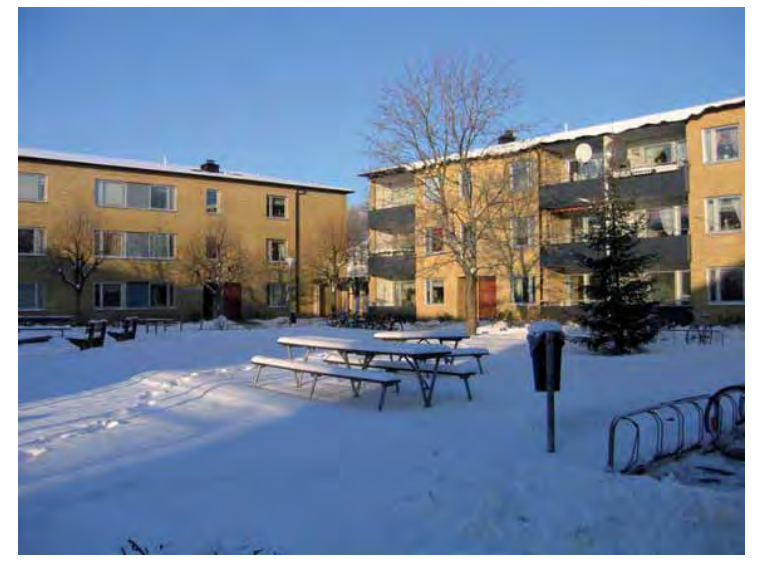

Figure 1: The apartment houses of the Brogården area.

The principal working form of Alingsåshem is Partnership, which means that the cooperating companies are selected for a period of five years in order to give the partners enough time for together developing and applying new ideas and methods. The renovation work in Alingsås is facilitated by the fact that a renowned Passive House Company with a leading passive house Architect Hans Eek is located in Alingsås. Hans Eek and Ing-Marie Odegren, the general manager of Alingsåshem have a similar view on housing refurbishment: "Our general view means to include economy, health, sustainability and quality in the total optimisation".

In the case of Brogården (Figure 1), the partnership consists of the following companies:

\section{Construction work}

- Building owner: Alingåshem AB

- Main entrepreneur: Skanska Sverige AB

- Design team

- Architect: efem arkitekter (Hans Eek)

- Structural engineer: WSP Byggprojektering AB

- Electricity consultant: COWI AB

- HVAC consultant: Andersson och Hultmark AB

- Measurements: SP Technical Research Institute of Sweden

- Advice and evaluation: Lund University, Energy and Building Design

Skanska Sverige AB is one of the larger Swedish construction companies and contributes to the project by further developing the initially selected methods for refurbishment and energy saving.

\section{Specific information about the settlement/neighbourhood structure}

\subsection{The buildings}

The dwellings of Brogården consist of a suitable mixture of 2-, 3- and 4-room apartments, plus kitchen, hall and sanitary rooms. The neighbourhood is a relatively open green area of 
$100000 \mathrm{~m}^{2}$, of which $6000 \mathrm{~m}^{2}$ are occupied by buildings (Figure 1). The total living area is $18500 \mathrm{~m}^{2}$, resulting in an average dwelling size of about $60 \mathrm{~m}^{2}$. This occupancy is typical for the living situation in minor cities in Sweden and is contributing to the relatively high living quality in Swedish provincial towns. The average age of the buildings in year 2010 is 37 year. The buildings in the quarter of Brogården are for pure residential applications, i.e. service and commercial locals are not foreseen there.

\subsection{Reason for refurbishment}

Due to the age of the buildings, the need for a refurbishment program was getting more and more accentuated. The tenants complained about draughts and low indoor temperatures. Earlier renovation of similar buildings showed that these complaints did not disappear after the renovation process; the buildings needed to be made more air-tight. Also the sanitary equipment was worn out and the general feeling was that the apartments were draughty and noisy. And last not least, the façade was in an urgent need of repair, façade bricks were just braking out of the façade (Figure 2).

Furthermore, the annual energy and maintenance were increasing with time. The house-owner's capital cost for the houses in the Brogården area were at the same order as the annual energy costs. Therefore it was the basic idea that the apartments should be renovated aiming at the energy levels of passive houses and that by saving energy costs the rent received could instead be used for amortizing the investments for the renovation.

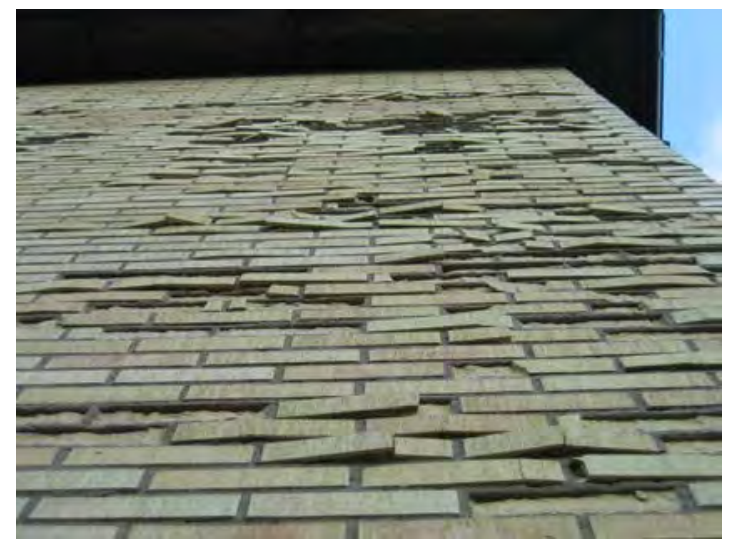

Figure 2: Details of the façades of the old building

\section{Sustainable building construction}

\subsection{The philosophy of sustainable construction}

The base for the refurbishment project Brogården is the consciousness of achieving a sustainable environment, which a. o. means also a reduced energy use on a sustainable level. The driving force for Alingsåshem was a generalised view about the role of a public company in the society, i. e. not only to achieve maximum profit for the company but to strive for the maximum profit of company and the society. Thus for the first time, such a generalised planning philosophy could be realised in Alingsås, after having fallen prey to short time profits on many other places.

In practice, the idea of sustainability was threefold:

Economy: In total, the project must be economic, otherwise the company will not survive and the tenants will be the looser.

Ecology: Environmental sustainability is one of the main issues which nowadays come into vogue at some places, but in the long term it is a necessity in all construction work.

Social welfare: The Stockholders (Municipality of Alingsås) have put the directive on Alingsåshem to work for the best of the tenants, with a long-term perspective on sustainability and not only looking on short run margins. 


\subsection{The realization}

The old buildings have been examined regarding possible moisture problems and air leakage. Even though the brick façade is worn out, there was no trace of moisture in the wooden wall construction. The new wall construction is based on a steel frame which allows an increased insulation area. For the outer protection, a new ceramic façade material is chosen, which gives the buildings the same architectural expression as the old brick façade, but which is able to withstand the influences of the climate for a long time. The floor of the balconies in the old construction consisted of the same concrete slab as the rest of the floor. This caused a large thermal bridge that now is eliminated by moving out the façade and balconies and hanging the balconies on the outside of the building. The result of this reconstruction is seen in Figure 3. This new solutions gives also a new, friendly look to the houses.

Figure 3: Renovated building in Alingsås with new façade material and new balcony construction.

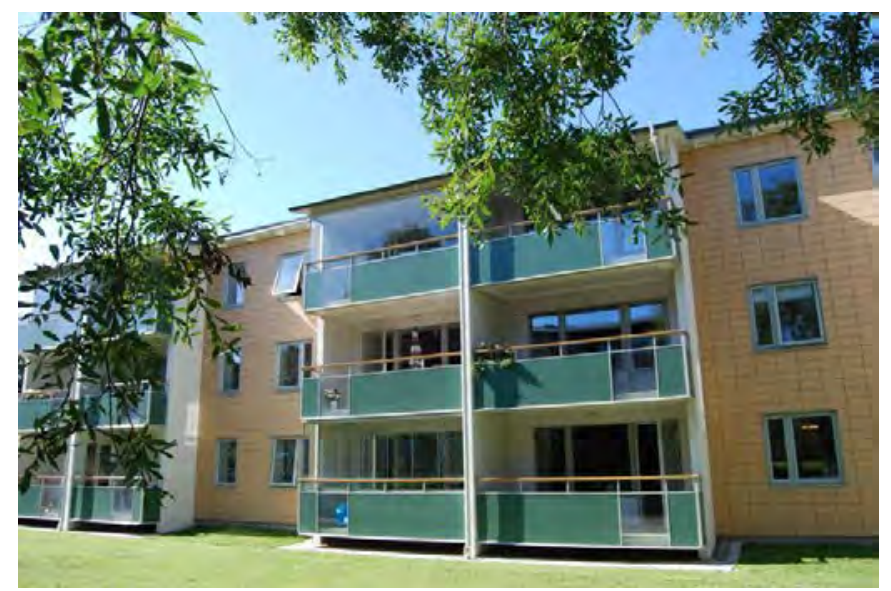

A big effort has been put on insulation and air tightness of the buildings. Figure 4 illustrates the construction and the ventilation system with incoming/exaust air heat exchangers. The air leakage rate is below $0.3 \mathrm{l} / \mathrm{s}, \mathrm{m}^{2}$ at $\pm 50 \mathrm{~Pa}$. In winter time, the air is preheated by district heating (which is existent from before).

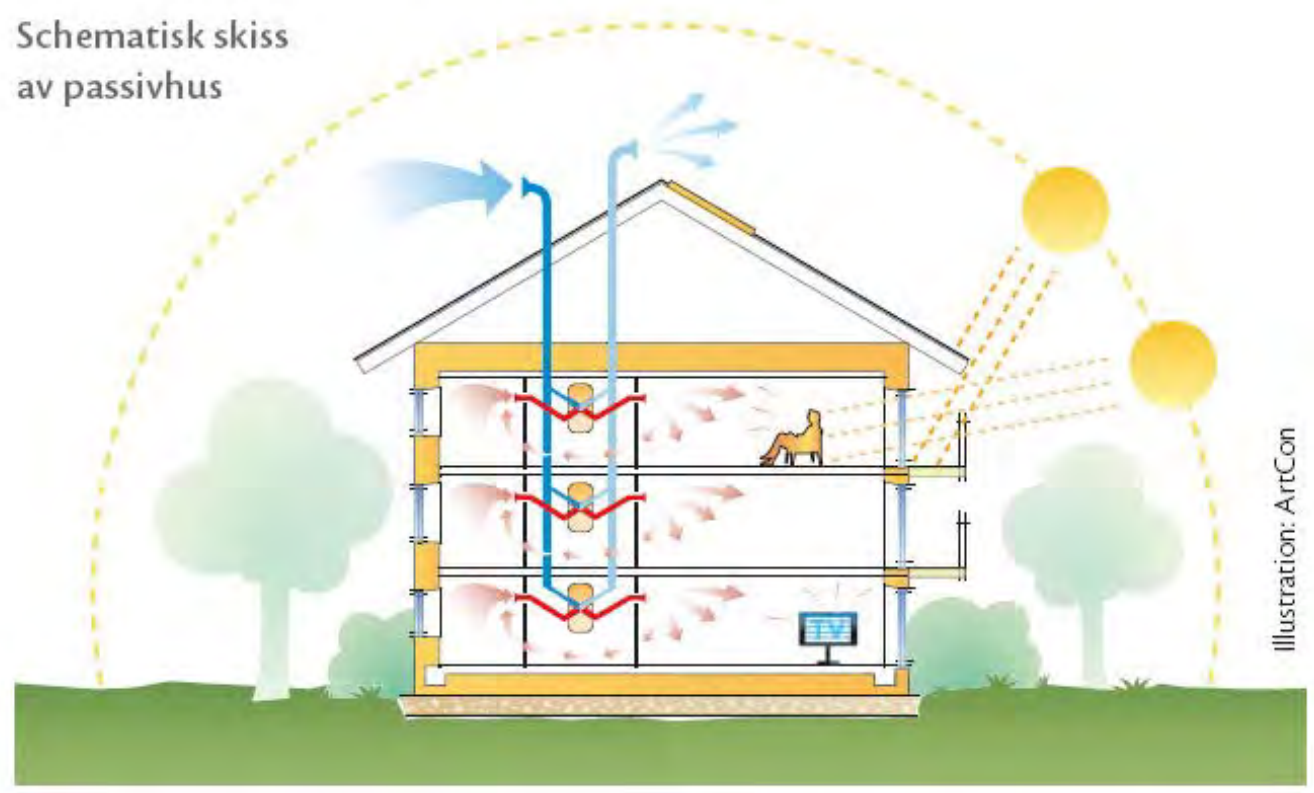

Figure 4: Principle of ventilation air heating system. Fresh air is transported via heat exchangers of each apartment to living room and sleeping rooms. Used air is taken from bath and kitchen. Attic insulation is $40 \mathrm{~cm}$, wall insulation $44 \mathrm{~cm}$ and ground floor insulation $20 \mathrm{~cm}$. Solar collectors provide domestic hot water. Balconies help to regulate solar radiation. Windows are of highest insulation standard. 
In all, the following measures were undertaken in connection with refurbishment:

- Thermal insulation on the ground floor and the outer walls

- Acoustic insulation on inner walls

- New façade material

- New (3-glass) windows

- Increased air-tightness, building envelope

- New ventilation with exhaust air heat exchanger

- Energy-efficient household appliances

- Solar collectors for domestic hot water (providing 50\% of DHW on annual basis)

- Moved balconies

- Entrance vestibules

- Increased access to indoor stores

- IT - access

- Individual heat metering - DHW and household electricity

- Handicap adapted entrance staircases, elevators and doors.

\subsection{Social aspects}

Beside energy efficiency, the project 'Brogården' aims to create a sustainable area of housing that promotes social integration. The projects main principles are accessibility, social structure and environment. The project started with a survey of the area to illustrate Brogården's qualities and its 'soul'. Through this survey, inadequacies in these aspects could be identified and the needs of Brogården's tenants documented. Customer focus groups with residents and various partnerships were created, f. i. with the elderly care services, municipal social management, child care services and schools, association activities and the social welfare administration. The customer focus groups were arranged through meetings with an idea workshop for the residents. It turned out that for the tenants it is was very important that families and single peoples could meet each other and - if possible - could also keep the physical neighbourhood. Another important factor for the living quality was the improved accessibility for handicapped people. That means that elderly people can stay longer time in their familiar environment.

\section{Savings on energy and environment}

Alingsås is situated about 100 km north-east of Gothenburg, i.e. in the southern Swedish climate zone. The annual mean temperature is about $6.5^{\circ} \mathrm{C}$, the mean monthly minimum temperature is $-3.1^{\circ} \mathrm{C}$ in February and the mean monthly maximum temperature is $15.6^{\circ} \mathrm{C}$ in July. The normal Sunshine time is 1715 hours/year and the annual global irradiation on a horizontal surface is about $960 \mathrm{kWh} / \mathrm{m}^{2}$.

The Brogården quarter was in the last years heated by district heat from the district heating company Alingsås Energy. This company runs since 1996 a biogas heating plant which drastically reduced the $\mathrm{CO}_{2}$ emission compared to the oil plant used before. In 2009 the specific $\mathrm{CO}_{2}$ emission from district heat production in Alingsås was $0.032 \mathrm{~kg} \mathrm{CO} / \mathrm{kWh}_{\text {th }}$ heat (including a primary energy factor of 1.7 [2]) and we assume the same value for the expected savings. For the impact of the use of electricity in Sweden, different ways are used for assessing the primary energy for energy calculations, essentially depending on two different ways to think about the energy use: Marginal use of energy or average use. When considering individual projects, it is recommended to use the marginal electricity use which is 
based on coal condensing power imported from Denmark and Germany. Hence the primary energy factor for the saved kWh electricity is relatively high. According to the State Energy Administration [3] the primary energy factor $=3.0\left(3 \mathrm{kWh}_{\mathrm{th}} / \mathrm{kW}_{\mathrm{el}}\right)$ and the related $\mathrm{CO}_{2}$ emission is $1 \mathrm{~kg} \mathrm{CO}_{2} / \mathrm{kWh}_{\mathrm{el}}$. So far, the evaluation of the new construction is only based on simulations, but measurements are going on. The supply of solar heat to the tap water system is based on expectations. Measurements and simulation results are summarised in Table 1:

Table 1: Energy demand, before and after renovation, if the proposed measures will be applied.

\begin{tabular}{lll}
\hline $\begin{array}{l}\text { Energy Demand } \\
\left(\mathbf{k W h} / \mathbf{m}^{2}, \mathbf{y r}\right)\end{array}$ & $\begin{array}{l}\text { Before (Measured average) } \\
\mathbf{( k W h} / \mathbf{m}^{\mathbf{2}} \mathbf{y r} \mathbf{)}\end{array}$ & $\begin{array}{l}\text { After (Calculated) } \\
\left.\mathbf{( k W h} / \mathbf{m}^{2}, \mathbf{y r}\right)\end{array}$ \\
\hline Space Heating & 115 & 30 \\
DHW & 30 & 25 \\
Household electricity & 39 & 27 \\
Electricity, common areas & 20 & 13 \\
\hline Sum & $\mathbf{2 0 4}$ & $\mathbf{9 5}$ \\
\hline
\end{tabular}

It can be seen from Table 1 that the expected energy use will be considerably decreased. The highest reduction belongs to the passive house conversion which reduces the need for bought energy by $74 \%$. The posts for household electricity and the electricity for operating the common areas are of course very uncertain estimates because they depend strongly on the lifestyle of the tenants. The operating energy of the fan-driven air heating system is included in the heat balance. The total electricity consumption is expected to be reduced by $32 \%$.

Table 2: Use of primary energy and $\mathrm{CO}_{2}$ emissions of the Brogården project

\begin{tabular}{|c|c|c|c|c|c|c|}
\hline \multirow[t]{2}{*}{ Specific energy use } & \multicolumn{2}{|c|}{ Before } & \multicolumn{2}{|c|}{$\begin{array}{c}\text { After } \\
\left(\mathrm{kWh} / \mathrm{m}^{2}\right)\end{array}$} & \multicolumn{2}{|c|}{ Saving } \\
\hline & Bought & Primary & Bought & Primary & Bought & Primary \\
\hline Heat & 115 & 195,5 & 30 & 51 & 85 & 144,5 \\
\hline Electricity & 89 & 267 & 65 & 195 & 24 & 72 \\
\hline Sum & 204 & 462,5 & 95 & 246 & 109 & 216,5 \\
\hline Spec. $\mathrm{CO}_{2}$ emission & \multicolumn{6}{|c|}{$\left(\mathrm{kg} / \mathrm{m}^{2}\right)$} \\
\hline Heat & 3,7 & & 1 & & 2,7 & \\
\hline Electricity & 89 & & 65 & & 24 & \\
\hline Sum & 93 & & 66 & & 27 & \\
\hline
\end{tabular}

As can be seen from Table 2, the total use of primary energy will be almost reduced to the half (53\%) whereas the resulting $\mathrm{CO}_{2}$ emission is reduced by $29 \%$. That means that the Brogården project in total will reduce $\mathrm{CO}_{2}$ emissions by 500 tons a year.

\section{Cost information}

The management of Alingsåshem divides the renovation cost into three parts. One part is energy saving, the second is investment in higher standard in the apartments (f. i. larger bathroom, new surface materials, etc.) and the third is the maintenance cost, the cost for renovations anyway needed. Since the need of renovation was so extensive, the cost for making the building energy efficient at the same time is not dominating.

Because we are dealing with an on-going project and continuous developments within it, the management is reluctant of telling exact costs for the moment. A cost indication gives the 
following estimates: Planned total costs are $300-400$ Million SEK, which is a cost of SEK15000 - 20000/m² living area. The costs of new apartments in Sweden are about the double of that. The reason for the high renovation costs is of course the fact that both outer walls and roof are substantially reconstructed.

These costs can be allocated to the following positions:

- $30 \%$ renovation

- $50 \%$ increase of standard and comfort

- $30 \%$ energy saving measures.

The saving of used energy corresponds to about $109 \mathrm{kWh} / \mathrm{m}^{2}$ or totally about $2 \mathrm{GWh} / \mathrm{yr}$, worth for the tenants ca. 3 Million SEK/year. Hence the amortisation time for the energy part is around 30 years. Another part concerns comfort, for which the tenants have to pay an increased hire with $1000 \mathrm{SEK} / \mathrm{month}$. The remaining position 'maintenance' goes on the expense of Alingsåshem which replaces direct service costs by depreciation of investment (at least in the next years). Alingsåshem expects that these costs will be depreciated in 20 years. In the recently decided next refurbishment stage for 3 buildings of Brogården, the costs were calculated to 55 million SEK for 65 flats, i.e. 850.000 SEK/flat.

\section{How the tenants react}

The organization plan has foreseen that the buildings should be renovated in a certain time sequence and the first building served as both demonstration and exercises object for the entrepreneurs. A demonstration apartment was also created in the first completed building, which allowed Brogården residents to visit and understand how their apartments were to be redeveloped. At most are three buildings under reconstruction at the same time. The duration of the refurbishment work is about 8 months. The tenants were supposed to move around in the areas empty flats. An important feature is therefore the continuous feedback from Alingsåshem to the tenants and vice versa. The tenants were informed about the special features and the economical consequences of the refurbishment work.

For this purpose, Alingsåshem publishes an in information folder on bimonthly basis and holds regularly information meetings with the tenants. The main entrepreneur Skanska participates with detailed explanations about the new techniques used in the refurbishment process. The tenants can express their degree of satisfaction with the different measures and their own situation.

Some people mentioned that it took a while until they understood the severity of the interference in their life, both economical and regarding the living. But in the long term, they think, it will be to their advantage. After the first buildings have been accomplished, there were claims about low winter and high summer temperatures as well as odours and noise from neighbour apartments [4]. Lessons from that were taken into the construction of the consequent buildings.

The biggest change for the individual tenant belongs to the economy, the hire is higher and the energy use (which earlier was included in the hire) has now to be paid separately. That means that a bath in the tub costs about $1 €$, which is a new experience to Swedish tenants. On the other hand the energy costs are lower than before and compensate partly for the increased hire bill. The total increase of the bill for hire and energy is around 1000 SEK per month. 


\section{Summarising conclusions}

- An important feature of the passive house refurbishment project is the political and social vision of the public (municipality) stockholders in the housing company, namely to apply an integrated view regarding an optimal solution for the living including economy, health, sustainability and live quality. An additional achievement is the internal selling of the project to the people who finally had to pay for it.

- A further ingredience is the engagement of an interested construction company in a winn/winn partnership with the building owner. The goals with the partnership is to develop working methods and building processes according to a learning curve which could be applied in a continuous way to the 300 apartments of the whole quarter. This partnership helped to start the project by minimizing risks and gives both partners economic and technical incentives according to the lessons learned during the project.

- An additional important feature in the project is the mutual communication with the tenants by keeping them informed by means of newsletters and meetings and by listening to their arguments and comments. This participation of the tenants increased their comprehension of the passive house ideas, the implications for the future living in these houses and finally the acceptance of the increased hire connected with the refurbishment.

- The benefit to the society is a demonstration that it is possible to reduce the energy use of existing buildings and especially of these mass produced buildings of the Million Programme that would have been worn out in the next 20 years. Hence it is demonstrated that they can be refurbished by satisfying strong new construction and environmental standards.

- The annual energy use was shown to be reduced by more than $100 \mathrm{kWh} / \mathrm{m}^{2}$ flat area, summing up to about $6-7 \mathrm{MWh} /$ per flat, which corresponds roughly to a reduction of 1,5 tons $\mathrm{CO}_{2}$ per flat and year. This is a relatively low value for achievable saving due to the fact that the heating energy is based entirely on renewable energy (biogas). The energy saving is mainly by achieved additional insulation, application of highest window standards, solar water heating and a low flow air-heating system. District heat is only used for peak power.

- The critical issue of the project is its relatively high costs, i.e. about half the cost for a completely new construction. However, the Standard of the buildings is that of new construction and it can be argued that if the tenants had to leave their homes and move in to newly constructed buildings, their hire would become higher. However, in order that this argument holds, the longevity of the refurbished buildings has to be demonstrated.

- Summarising, we can state that the expected heating energy is with $55 \mathrm{kWh} / \mathrm{m}^{2}$ annual heating energy relatively close to the passive house standard $45 \mathrm{kWh} / \mathrm{m}^{2}$ for southern Sweden. If this value will be reached in practice, it would stand for a real breakthrough as far as refurbishment projects for the Million Programme buildings are concerned.

\section{References}

[1] Janson, Ulla: Passive houses in Sweden, Licentiate Thesis, Lund University (2008). Report EBD-T--08/9.

[2] Swedish Energy Adminstration STEM: Koldioxid värdering av Energianvändning (Carbon dioxid evaluation for energy use). Eskilstuna 2008.

[3] Climate presentation of Alingsås Energi, 2009.

[4] Brogårdsbladet, nr. 25, oct 2010. www.alingsashem.se/index.php?page=brogardsbladet. 